\title{
Residential heat pumps in the future Danish energy system
}

\author{
Petrovic, Stefan; Karlsson, Kenneth Bernard
}

Published in:

Energy

Link to article, DOI:

10.1016/j.energy.2016.08.007

Publication date:

2016

Document Version

Peer reviewed version

Link back to DTU Orbit

Citation (APA):

Petrovic, S., \& Karlsson, K. B. (2016). Residential heat pumps in the future Danish energy system. Energy, 114, 787-797. https://doi.org/10.1016/j.energy.2016.08.007

\section{General rights}

Copyright and moral rights for the publications made accessible in the public portal are retained by the authors and/or other copyright owners and it is a condition of accessing publications that users recognise and abide by the legal requirements associated with these rights.

- Users may download and print one copy of any publication from the public portal for the purpose of private study or research.

- You may not further distribute the material or use it for any profit-making activity or commercial gain

- You may freely distribute the URL identifying the publication in the public portal

If you believe that this document breaches copyright please contact us providing details, and we will remove access to the work immediately and investigate your claim 


\title{
Residential heat pumps in the future Danish energy system
}

\author{
Stefan N. Petrović* \\ Department of Management Engineering \\ Technical University of Denmark, Kongens Lyngby, Denmark \\ Kenneth B. Karlsson \\ Department of Management Engineering \\ Technical University of Denmark, Kongens Lyngby, Denmark
}

\begin{abstract}
Denmark is striving towards $100 \%$ renewable energy system in 2050 . Residential heat pumps are expected to be a part of that system.

We propose two novel approaches to improve the representation of residential heat pumps: Coefficients of performance (COPs) are modelled as dependent on air and ground temperature while installation of ground-source heat pumps is constrained by available ground area. In this study, TIMES-DK model is utilised to test the effects of improved modelling of residential heat pumps on the Danish energy system until 2050.

The analysis of the Danish energy system was done for politically agreed targets which include: at least $50 \%$ of electricity consumption from wind power starting from 2020 , fossil fuel free heat and power sector from 2035 and $100 \%$ renewable energy system starting from 2050. Residential heat pumps supply around $25 \%$ of total residential heating demand after 2035. The improved modelling of residential heat pumps proved to have influence on the results. First, it would be optimal to invest in more ground-source heat pumps, but there is not enough available ground area. Second, the total system costs are higher when COPs are modelled as temperature-dependent compared to fixed COPs over a year.
\end{abstract}

Keywords: energy modelling; spatial constraints; GIS; seasonal COP; heat demand; heat supply

${ }^{*}$ Corresponding author. Tel.: +45 24655732

E-mail addresses: stpet@dtu.dk (S.N. Petrović), keka@dtu.dk (K.B. Karlsson). 


\begin{tabular}{|c|c|c|c|}
\hline Nomenclature & & $P_{h}(t)$ & Heat power in time $t$ \\
\hline $\mathrm{R}$ & Set of regions & $\mathrm{P}_{\mathrm{e}}(\mathrm{t})$ & Electrical power in time $\mathrm{t}$ \\
\hline $\mathrm{r}$ & Region & $\mathrm{COP}_{\mathrm{av}}$ & $\begin{array}{l}\text { Average COP of a residential } \\
\text { heat pump }\end{array}$ \\
\hline YEARS & $\begin{array}{l}\text { Set of years for which there } \\
\text { are costs }\end{array}$ & $W_{h}$ & $\begin{array}{l}\text { Maximal annual heating } \\
\text { demand which can be covered } \\
\text { by a ground-source heat pump }\end{array}$ \\
\hline $\mathrm{y}$ & Year & $P_{h, \text { spec }}$ & $\begin{array}{l}\text { Specific extraction power from } \\
\text { the ground }\end{array}$ \\
\hline NPV & $\begin{array}{l}\text { Net present value of the total } \\
\text { system cost for all regions }\end{array}$ & $A_{a v}$ & Available parcel area \\
\hline $\operatorname{ANNCOST}(r, y)$ & $\begin{array}{l}\text { Total annual cost in region } r \\
\text { and year } y\end{array}$ & $k_{\text {area }}$ & $\begin{array}{l}\text { Reduction coefficient of } \\
\text { available parcel area for burring } \\
\text { of horizontal pipes }\end{array}$ \\
\hline$d_{r, y}$ & General discount rate & $T_{f l h}$ & $\begin{array}{l}\text { Full load fours of ground- } \\
\text { source heat pumps over a year }\end{array}$ \\
\hline$R E F Y R$ & Reference year for discounting & & \\
\hline
\end{tabular}

\section{Introduction}

The long term goal in the Danish society is to become $100 \%$ renewable in all sectors of the energy system from 2050. The intermediate goals include achieving $50 \%$ of electricity consumption from wind starting in 2020 and $100 \%$ renewable power and heat production from $2035[1,2]$. Achieving such an energy system requires significant efficiency improvements in the chain production-transmission-distribution-end-use of electricity and heat, accompanied by energy conservation measures.

Common understanding of the heat supply configuration in the future Danish energy system includes district heating in areas with high heat density and individual heating technologies in areas with low heat density. In the light of renewable energy targets, district heating will be switching from coal-based CHPs to large heat pumps, waste incinerations and waste heat from production of biofuels. Existing individual heating technologies will be replaced by technologies fuelled by renewable energy, such as residential heat pumps. New buildings will be built according to high standards of energy efficiency while introduction of heat saving measures will decrease heating demands in existing buildings.

Previous studies have shown that residential heat pumps are important elements of the future Danish energy system. Münster et al. [3] have developed three scenarios for the Danish energy system with the intention to analyse the interaction between the electricity market and district heating in the light of heat savings and taxes and support mechanisms. They have found that in all scenarios the individual heat production completely changes from oil and natural gas to residential heat pumps already in 2025. Similar research questions have been analysed in $[4,5]$. Their conclusion is that district heating should be gradually expanded around cities and towns while residential heat pumps should supply rural and remote areas in both current and future Danish energy system. According to IDA's Climate Plan 2050 [6, 7] district heating production will increase in the future despite significant reduction of heating demands in buildings. District heating will mainly be based on biomass and large scale heat pumps, while two thirds of individual heating will be produced from heat pumps. Analysis of the Danish energy system in 2050 done by Lund et al. [8] showed that heat supply configuration should be composed of district heating and residential heat pumps, while 
heating demand should be halved compared to today's values. Two main scenarios for the Danish energy system in 2025 are analysed in [9]. It is concluded that from a socioeconomic point of view, heat pumps seem to be cost-effective in buildings not connected to district heating. Mathiesen et al. [10] have analysed how the heating sector can reduce its consumption of biomass. They have shown that district heating systems are important in limiting the dependence on biomass but have also recommended ground-source heat pumps for individual heating systems in areas with low heat density. Torekov et al. [11] have compared the costs of heat supply to residential buildings from private-economic and socioeconomic perspective. They have concluded that from the socio-economic perspective airsource heat pumps are the cheapest of the individual heating systems and in the most cases cheaper than the collective heating systems. In a technical analysis of future renewable energy systems of Frederikshavn and Aalborg individual heat pumps and solar collectors were the only heating sources besides district heating $[12,13]$.

The interactions of residential heat pumps with the energy system were analysed in several studies. The Danish energy system with high shares of wind power, CHPs and district heating is analysed in [14] and it is shown that the installation of heat pumps can contribute to the integration of wind power and provide significant reductions in excess electricity production and fuel consumption. Hedegaard and Münster [15] used the Danish energy system in year 2030 with $50-60 \%$ of wind power and $55 \%$ of residential buildings heated by district heating as a case study. They have shown that heat pumps significantly contribute to the integration of wind power, reduction of system costs, fuel consumption and $\mathrm{CO}_{2}$ emissions. Mathiesen et al. [16] have applied Smart Energy Systems approach to design a future Danish energy system based on $100 \%$ renewable energy. They have concluded that with more than $20-25 \%$ wind power of the electricity demand it is necessary to install large-scale and individual heat pumps in order to effectively integrate fluctuating wind power. In a nearly $100 \%$ renewable energy system of Scandinavian countries and Germany in 2060, heat pumps, electrolysis plants and biomass CHPs are providing the needed flexibility caused by variable production from wind power and photovoltaics [17]. Health externalities are added to the optimisation model Balmorel in [18]. It is shown that investment and operation decisions favour modern pollution-free energy producers such as wind turbines and heat pumps in high health impact areas and traditional coal-based generation in the low impact areas.

No existing studies have been identified in which the operation of residential heat pumps is described by temperature-dependent coefficients of performance (COP). In addition to that, no existing studies dealing with whether there is enough ground area for installation of ground-source heat pumps have been identified. These two issues are therefore the main subjects of this study. We improve the modelling of residential heat pumps by introducing temperature-dependent COPs and use GIS tools to determine the available area for installation of ground-source heat pumps. After that, we use TIMES-DK model of the Danish energy system to test the impact of the improved modelling of residential heat pumps on their investments and operation. TIMES-DK model calculates the cost-optimal solution for the whole energy system until the end of the analysed period and thus show the role of residential heat pumps. Our analysis is done for the existing politically agreed renewable energy targets until 2050. However, we don't focus on the analysis of targets or ways how to fulfil them. The effects of the improved modelling on the heat supply configuration, the total system costs, $\mathrm{CO}_{2}$ emissions and fuel consumption have also been quantified.

The manuscript is structured as follows. Section 2 briefly describes the operational principles of TIMES models and general features of TIMES-DK. The detailed description of improved modelling of residential heat pumps can be found in sub-section 2.3. Section 3 lists the analysed scenarios. Section 4 presents the results of energy systems analysis. The sensitivity analysis is presented in Section 5. The results are discussed in Section 6. The conclusion is 
given in Section 7. Finally, the areas which should be addressed within the future work are presented in Section 8.

\section{Methodology}

\subsection{TIMES model generator}

The following description of TIMES models is a combination of authors' insights from working with TIMES and references [19-23]. TIMES (The Integrated MARKAL-EFOM System) was developed and is maintained by the Energy Technology Systems Analysis Programme (ETSAP), an Implementing Agreement of the International Energy Agency (IEA), established in 1976. TIMES is a technology-rich, bottom-up model generator utilised for long-term analysis and planning of regional, national and multi-national energy systems. It is also techno-economic, partial equilibrium model-generator assuming full foresight and perfectly competitive markets. Thus, it covers "4E" aspects of energy systems - energy, economy, environment and engineering.

TIMES models are linear programming problems which consist of the minimization of an objective function defined as a mathematical expression of decision variables, subject to constraints also expressed mathematically. In other words, TIMES models are choosing the investments, operation, primary energy supply and imports/exports over all regions and all time periods in an energy system in such a way that the objective function is minimized. The objective function in TIMES models represent the total system costs discounted to the reference year for discounting and it is expressed with the following equation:

$$
N P V=\sum_{r=1}^{R} \sum_{y \in Y E A R S}\left(1+d_{r, y}\right)^{R E F Y R-y} \cdot \operatorname{ANNCOST}(r, y),
$$

where the used symbols have the following meaning:

NPV - Net present value of the total system cost for all regions, i.e. the TIMES objective function,

$\operatorname{ANNCOST}(r, y)$ - Total annual cost in region $r$ and year $y$. This cost include investment, fixed and variable annual Operation and Maintenance (O\&M) costs, import/export costs/revenues, cost of resource extraction, taxes and subsidies, salvage values at the end of the analysed period, etc,

$d_{r, y}$ - General discount rate,

$R E F Y R$ - Reference year for discounting,

YEARS - Set of years for which there are costs, as well as the Salvage Value at the end of the analysed period.

While minimizing total discounted cost TIMES models must satisfy a large number of constraints which express the physical and logical relationships in order to properly depict the associated energy system. 


\subsection{TIMES model for Denmark}

The TIMES model for Denmark (TIMES-DK) includes all sectors of the Danish energy system. It is developed by Energy Systems Analysis group, DTU Management Engineering, E4SMA and the IntERACT team from the Danish Energy Agency. Both authors of the current paper have been members of the project team. In the present paper DTU's version of TIMES-DK is used. For detailed description of the model, the reader should consult model documentation at www.ens.dk/interact.

\subsubsection{Geographical and temporal structure}

From a geographical point of view TIMES-DK model is national, multi-regional energy system model. Denmark is represented with two regions, East Denmark (DKE) and West Denmark (DKW).

Time in energy system models is often represented in a form of chronological values of same duration. In TIMES-DK, chronological structure is not established. Instead, time is represented in form of time-slices. Time-slices represent hours with similar characteristics within the same year. Time-slices have different lengths, ranging from 1 hour up to 1409 hours. One or more years are grouped into time-periods.

\subsubsection{Domestic energy resources and trade}

The domestic and imported, renewable and non-renewable resources are utilised in TIMESDK to produce energy services demanded by energy consumers within the Danish energy system.

The domestic potentials of non-internationally traded fuels are defined in the model. Domestic onshore wind, offshore wind and wave potentials are obtained from [24], while domestic PV, solar thermal and geothermal potentials are obtained from [25]. The domestic straw, woodchips, wood waste and slurry potentials are based on [26].

The domestic combustible waste potentials are obtained from FRIDA model [27], while its import from abroad is not enabled in TIMES-DK. The long-term price projections for straw, woodchips, wood waste and slurry are obtained from [28]. For internationally traded fuels, long-term price projections are obtained from [29] and their import is not constrained in the model.

The electricity trade is enabled in TIMES-DK. The electricity interconnections with neighbouring countries are represented with technical capacities and import/export price projections from/to each of the neighbouring countries. The price projections, existing capacities and planned expansions of transmission capacities are adopted according to [30].

\subsubsection{Residential sector}

The residential sector in TIMES-DK is represented by electricity and heating demands of Danish residential buildings. The data about buildings in the base year ${ }^{1}$ are obtained from the BBR dataset [31]. The net demand for space heating and domestic hot water is calculated for

\footnotetext{
${ }^{1}$ Base year is the starting year of the model. In case of TIMES-DK, the base year is 2010.
} 
360 building groups according to the methodology presented in [32] and aggregated according to following properties:

- Construction period - buildings built before 1972, after 1972 and new buildings,

- Building type - Single-family and Multi-family buildings according to classification used in Danish energy statistics [33],

- Region - DKE and DKW,

- Position relative to existing $\mathrm{DH}^{2}$ areas - Central, Decentral and Individual areas.

The heat demand of new buildings is assumed to be the same as defined in the building regulations [34]. The electricity consumption of household appliances and their lifetimes are obtained from "Elmodelbolig" survey [35].

After the base year, heat demand in the residential sector is driven by the change in the heated area of buildings and the implementation rate of heat saving measures. The construction and demolition rates are assumed according to [36, 37] and they are distributed across the building stock proportionally to heated areas in the base year. The electricity demand in the residential sector is driven by the increase in number of electrical appliances and their efficiency.

There are two options for heat supply and two options for electricity supply of buildings both heat and electricity can be produced centrally in the system and transmitted to the consumers or they can be produced locally.

In Energy Producers Count [38] district heating producers are grouped into Central and Decentral. The district heating areas are supplied from Central and Decentral plants and are thus named Central and Decentral DH areas, respectively. Accordingly, residential buildings located within or close to Central and Decentral DH areas belong to Central and Decentral buildings, respectively. The buildings located far away from existing DH areas belong to Individual buildings. For each of these building groups, potentials and costs of heat saving measures are defined according to methodology presented in $[32,39]$.

\subsubsection{Power and heat sector}

The power and heat sector in TIMES-DK can be seen as producers of electricity and district heat. The energy system in the base year is described with the number and installed capacities of units. The units are grouped by size, type and region. The share of the base year stock which is decommissioned in each of the time periods, also known as retirement profile, is specified for each group. The data about existing stock are obtained from [38, 40].

Each of the existing production facilities is represented with following parameters: efficiency, fixed and variable O\&M costs and availability factor. The techno-economic parameters used for describing the existing stock are obtained from [41]. The capacities of existing DH grids in the base year are obtained from [38, 42]. In addition to the parameters used for modelling of the existing stock, investment costs are used to describe new technologies. Ref. [41] is used as a source of techno-economic parameters for new technologies.

\subsubsection{Other sectors}

Besides residential and power and heat sectors, seven other sectors are included in TIMESDK: Transportation, Private service, Public service, Construction activity, Manufacturing,

\footnotetext{
${ }^{2} \mathrm{DH}$ will be denoting district heating throughout the paper.
} 
Agriculture and Other sectors. Since the current article deals with the improved modelling of residential heat pumps, these sectors are not described.

\subsection{Modelling of residential heat pumps}

Three types of residential heat pumps are modelled for both Single-family and Multi-family buildings. The techno-economic parameters used for modelling of residential heat pumps are presented in

Tables and figures

together with their expected improvements until 2050. The parameters are based on "Technology data for Energy plants" [41].

Table 1. Parameters used for modelling of residential heat pumps

\begin{tabular}{|c|c|c|c|c|c|c|c|c|c|c|c|}
\hline & & \multicolumn{5}{|c|}{ Single-family buildings } & \multicolumn{5}{|c|}{ Multi-family buildings } \\
\hline Type & Year & $\begin{array}{c}\text { Inv. } \\
\mathrm{c.} \\
\left(\frac{M D K K}{M W}\right)\end{array}$ & $\begin{array}{l}\text { Lifetime } \\
\text { (years) }\end{array}$ & $\begin{array}{c}\text { Fix. } \\
\text { O\&M c. } \\
\left(\frac{M D K K}{M W \cdot \text { year }}\right)\end{array}$ & $\begin{array}{c}\text { Var. } \\
\text { O\&M } \\
\mathrm{c} . \\
\left(\frac{M D K K}{P J}\right)\end{array}$ & $\begin{array}{l}\text { Availability } \\
\text { factor }\end{array}$ & $\begin{array}{l}\text { Inv.c. } \\
\left(\frac{M D K K}{M W}\right)\end{array}$ & $\begin{array}{l}\text { Lifetime } \\
\text { (years) }\end{array}$ & $\begin{array}{c}\text { Fix. } \\
\text { O\&M c. } \\
\left(\frac{M D K K}{M W \cdot y e a r}\right)\end{array}$ & $\begin{array}{c}\text { Var. } \\
\text { O\&M } \\
\text { c. } \\
\left(\frac{M D K K}{P J}\right)\end{array}$ & $\begin{array}{l}\text { Availability } \\
\text { factor }\end{array}$ \\
\hline \multirow{4}{*}{$\begin{array}{l}\text { Air- } \\
\text { to- air }\end{array}$} & 2015 & 4.02 & \multirow{4}{*}{20} & \multirow{4}{*}{0.06} & \multirow{4}{*}{$4)^{2}$} & \multirow{4}{*}{0.12} & 4.02 & \multirow{4}{*}{20} & \multirow{4}{*}{0.06} & \multirow{4}{*}{0} & \multirow{4}{*}{0.12} \\
\hline & 2020 & 3.87 & & & & & 3.87 & & & & \\
\hline & 2030 & 3.58 & & & & & 3.58 & & & & \\
\hline & 2050 & 3.43 & & & & & 3.43 & & & & \\
\hline \multirow{4}{*}{$\begin{array}{c}\text { Air- } \\
\text { to- } \\
\text { water }\end{array}$} & 2015 & 9.69 & \multirow{4}{*}{20} & \multirow{4}{*}{0.10} & \multirow{4}{*}{0} & \multirow{4}{*}{0.20} & 7.45 & \multirow{4}{*}{20} & \multirow{4}{*}{0.01} & \multirow{4}{*}{0} & \multirow{4}{*}{0.20} \\
\hline & 2020 & 8.94 & & & & & 7.45 & & & & \\
\hline & 2030 & 8.94 & & & & & 6.71 & & & & \\
\hline & 2050 & 8.20 & & & & & 6.71 & & & & \\
\hline \multirow{4}{*}{$\begin{array}{l}\text { Brine } \\
\text {-to- } \\
\text { water }\end{array}$} & 2015 & 12.67 & \multirow{4}{*}{$30^{3}$} & \multirow{4}{*}{0.10} & \multirow{4}{*}{0} & \multirow{4}{*}{0.20} & 8.20 & \multirow{4}{*}{30} & \multirow{4}{*}{0.01} & \multirow{4}{*}{0} & \multirow{4}{*}{0.20} \\
\hline & 2020 & 11.92 & & & & & 8.20 & & & & \\
\hline & 2030 & 11.18 & & & & & 7.45 & & & & \\
\hline & 2050 & 10.43 & & & & & 6.71 & & & & \\
\hline
\end{tabular}

The relation between input and output of residential heat pumps is usually represented in energy system models with the following equation [3-5, 8-15, 17, 18]:

$$
P_{h}(t)=C O P_{a v} \cdot P_{e}(t)
$$

where $\mathrm{P}_{\mathrm{h}}(\mathrm{t})$ and $\mathrm{P}_{\mathrm{e}}(\mathrm{t})$ are heat output and electrical input power in time $\mathrm{t}$, while $\mathrm{COP}_{\mathrm{av}}$ is average COP of a residential heat pump. In addition to that, maximal investments in groundsource heat pumps are usually not constrained in energy system models for Denmark [3-5, 8, $9,10,11,14,15,17,18]$.

In the following sub-sections, two novel approaches regarding modelling of residential heat pumps are introduced. First, COPs are modelled as temperature-dependent instead of traditional approach in which constant COPs over whole year are used. Second, availability of ground area is used as a constraining factor for installation of ground-source heat pumps.

\subsubsection{Temperature-dependent COPs}

\footnotetext{
${ }^{3}$ The lifetime of 30 years represents the joint lifetime of a ground-source heat pumps and horizontal pipes.
} 
Residential HPs are often regarded as environmentally friendly and efficient heat sources. For example, with average COPs of 3 and 3.3, ASHPs and GSHPs ${ }^{4}$ on average deliver 3 and 3.3 units of heat for each unit of electricity taken from an external source. Even though constant values of COPs over time are often used, they are not constant over time. They are depending on the temperature of a heating source, i.e. higher temperatures of heating sources imply higher COPs and vice versa. As a result of that, residential HPs perform poorer in winters than in summers. Since air temperature is varying more over a year than ground temperature, ASHPs are performing poorer in winters than GSHPs. On the other hand, heating demands in winters are the highest over a year. To sum up the previous discussion: "COPs of residential HPs are changing during a year. They are high when heat demands are low and low when heat demands are high". To account for the fact that COPs are changing over time, average seasonal COPs are included in the model. The rationale behind including seasonal instead of time-slice specific COP factors is that it gives sufficient insight into operation of residential HPs but doesn't significantly increase computational times.

The average hourly air temperatures and average daily ground temperatures for seven temperature regions in Denmark are obtained from the dataset prepared by the Danish Meteorological Institute [43]. Due to small variations in soil temperatures among temperature regions, single daily ground temperature variation is assumed for whole Denmark. The variations of air temperature over a year are more regional-dependent, so different hourly temperature variations are assumed for DKE and DKW.

In the review of residential heat pumps done by Staffel [44, 45], COPs of over 100 models are presented as functions of temperature difference between heat source (air or ground) and heat sink (hot water output). These functions are approximated with linear functions and used in TIMES-DK. In the present paper the temperature of heat sink of $55^{\circ} \mathrm{C}$ is assumed. The assumed variations of air and ground temperatures, calculated variations of COPs and average seasonal COPs are presented in Error! Reference source not found., Error! Reference source not found. and Error! Reference source not found. respectively.

\footnotetext{
${ }^{4}$ Abbreviations HP, GSHP and ASHP denote heat pumps, ground-source and air-source heat pump, respectively.
} 


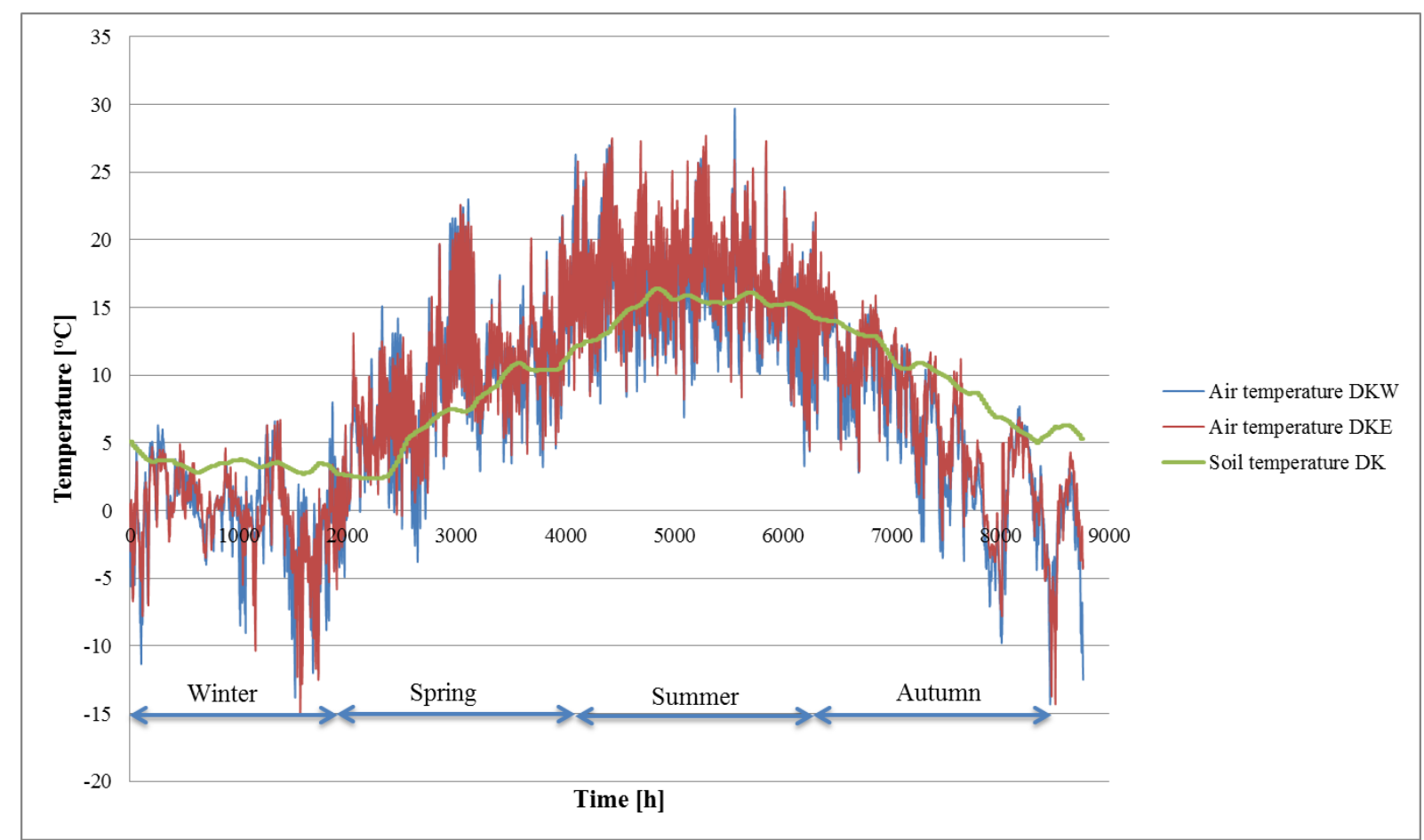

Figure 1. Change in air and ground temperatures used for modelling of ASHPs and GSHPs

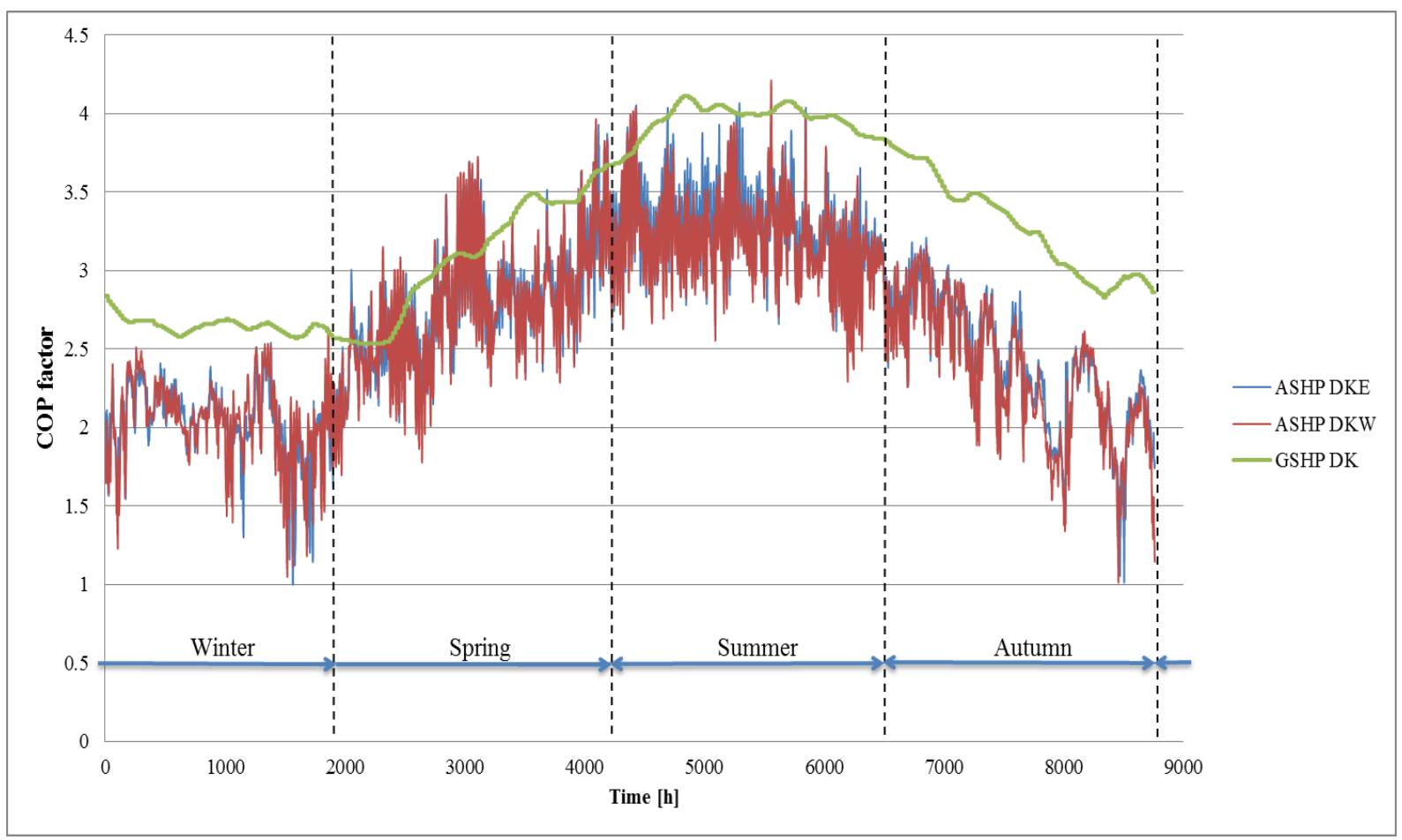

Figure 2. Change in COP factors of ASHPs and GSHPs

Table 2. COPs for ASHPs and GSHPs in different seasons and different regions

\begin{tabular}{|c|c|c|c|c|c|c|}
\hline \multirow{2}{*}{$\begin{array}{c}\text { Type of } \\
\text { heat pump }\end{array}$} & \multirow{2}{*}{ Region } & \multicolumn{3}{|c|}{ Seasons } & \multirow{2}{*}{$\begin{array}{c}\text { Yearly } \\
\text { average }\end{array}$} \\
\cline { 3 - 5 } \\
\cline { 3 - 5 }
\end{tabular}




\begin{tabular}{|c|c|c|c|c|c|c|}
\hline GSHP & Denmark & 3.05 & 3.95 & 3.40 & 2.69 & 3.27 \\
\hline ASHP & $\begin{array}{c}\text { East } \\
\text { Denmark }\end{array}$ & 2.72 & 3.30 & 2.54 & 2.02 & 2.65 \\
\hline ASHP & $\begin{array}{c}\text { West } \\
\text { Denmark }\end{array}$ & 2.70 & 3.22 & 2.47 & 2.01 & 2.60 \\
\hline
\end{tabular}

\subsubsection{Spatial constraints}

Ground-source heat pumps provide space heating and domestic hot water during whole year by extracting heat from the ground, heating it up and transferring it into the buildings. The main elements of GSHPs are: pipes with circulating fluid buried into a ground, heat pump and heat distribution pipes and interior radiators or underfloor heating. The buried pipes require certain space to be able to extract enough heat from the ground and thus cover buildings' heating demands. As an example, farmhouses with moderate heated areas and spacious backyards surely have enough space to base their heat supplies on GSHPs. On the other hand, multi-story buildings with high heating demands and small available parcel area don't have enough space for burring the pipes needed for operation of GSHPs and thus can only use it for covering parts of annual heating demands. GIS tools incorporated in ArcGIS 10.1 tool are applied to find the total heating demand which can be covered by GSHPs. The applied procedure is as follows:

1. All parcels in Denmark have been projected on top of the background map in ArcGIS 10.1. All road parcels have been excluded from further consideration about placement of GSHPs.

2. The layer containing boundaries of buildings has been projected on top of the previous layer.

3. DTU energy atlas with all residential buildings presented as points has been projected on top of the previous layers. This layer contains information about buildings' heated area, use, construction year, type of heating installations (district heating, electrical heating, natural gas boiler, etc.) fuel used (electricity, natural gas, etc.) and calculated annual heat demand.

4. The available areas within parcels have been calculated as a difference between total parcel area and area edged by buildings' boundaries. As an example, the available parcel area is marked with light green colour in Error! Reference source not found.. The parcels without buildings positioned within their area are excluded from further consideration. 


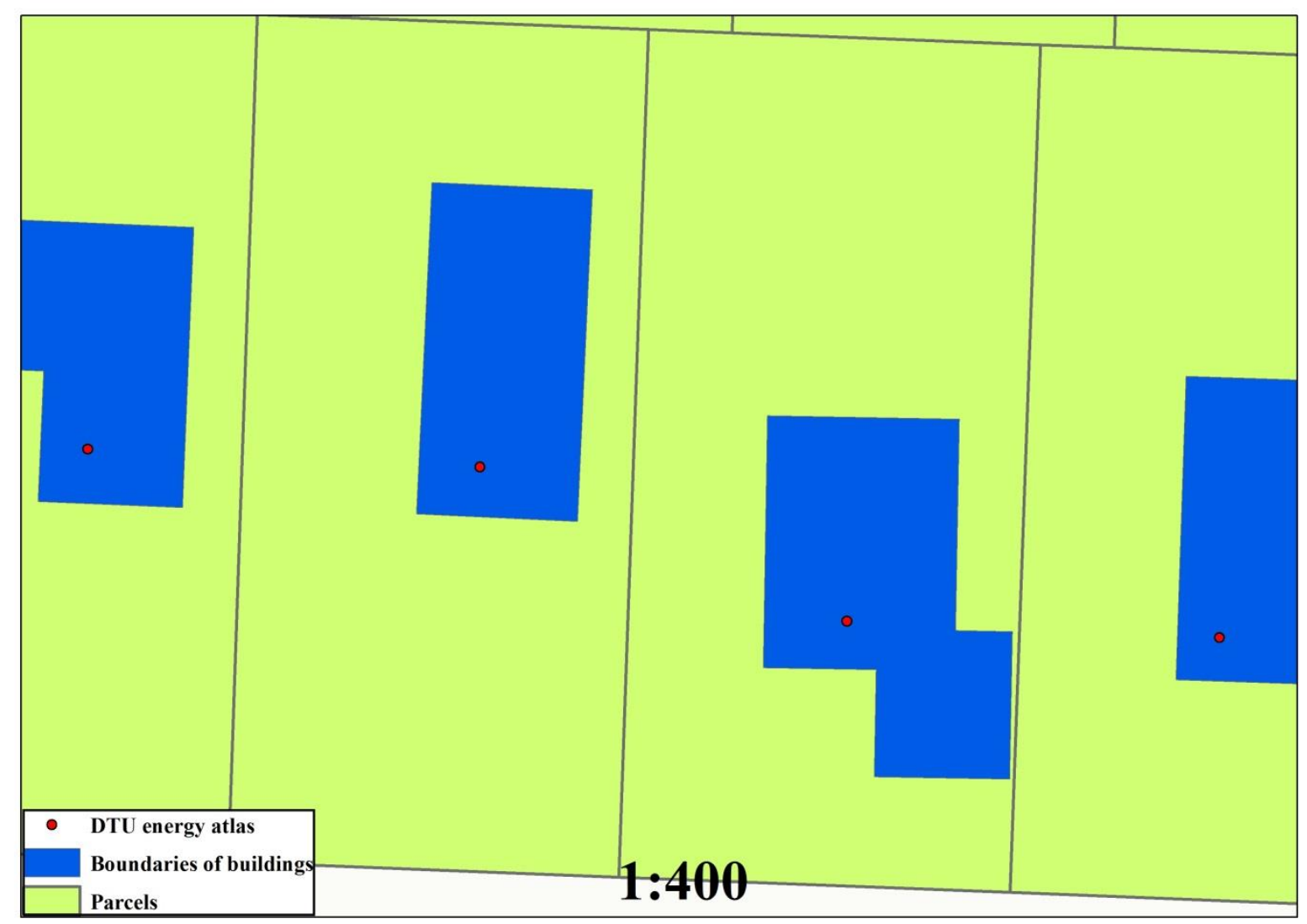

Figure 3. Parcels and boundaries of buildings

5. The maximal annual heating demand which can be covered by a GSHP has been calculated for each parcel as follows:

$$
W_{h}=P_{h, s p e c} \cdot A_{a v} \cdot k_{\text {area }} \cdot T_{f l h} \cdot \frac{\operatorname{COP}_{a v}}{\operatorname{COP}_{a v}-1}
$$

where used symbols have the following meaning:

$W_{h}(k W h)$ - Maximal annual heating demand which can be covered by a GSHP, $P_{h, \text { spec }}$ - Specific extraction power from the ground. The value of $20 \frac{\mathrm{W}}{\mathrm{m}^{2}}$ was used as an average value from $[46,47]$.

$A_{a v}$ - Available parcel area calculated in the previous step,

$k_{\text {area }}$ - Reduction coefficient showing the percentage of a parcel area which is available for burring horizontal pipes. It acknowledges the differences in geometries of parcels. Value of $k_{\text {area }}=0.5$ is used for all parcels.

$T_{f l h}$ - Full load fours of GSHP over a year. Value of $T_{f l h}=1800 h$ is used according to $[41,47]$.

COP $a v$ - Annual average COP. Value of 3.3 is used according to [41] and Error! Reference source not found.

6. The maximal potentials for covering heating demands by GSHPs calculated in the previous step are aggregated based on region (DKE and DKW) and type of buildings (Single-family and Multi-family buildings), as presented in Error! Reference source not found. The parcels supplied by district heating are not considered to be candidates for supply by GSHPs and are thus excluded from this aggregation. 
Table 3. Available ground area for installation and maximal heat demand possible to supply from GSHPs

\begin{tabular}{|l|l|r|r|}
\hline Region & Building type & Useable area $\left(\mathrm{km}^{2}\right)$ & Heat demand $(\mathrm{TWh})$ \\
\hline DKE & Single-family & 2194 & 4.8 \\
\hline DKE & Multi-family & 37 & 0.7 \\
\hline DKW & Single-family & 6402 & 6.7 \\
\hline DKW & Multi-family & 45 & 0.3 \\
\hline
\end{tabular}

\section{Analysed scenarios}

Three scenarios have been compared in the present analysis:

1. Base scenario includes politically agreed renewable energy targets declared in $[1,2]$ :

- At least $50 \%$ of electricity consumption needs to be produced from wind power starting from 2020.

- Use of fossil fuels is forbidden in the production of electricity and heat starting from 2035.

2. NoIHP (No Installation of Heat Pumps) - The only difference from Base scenario is that installation of residential ASHPs and GSHPs is not allowed.

3. NoCIHP (No Constrains on Installation of Heat Pumps) - The only difference from Base scenario is that installation of residential GSHPs is unconstrained, i.e. constraints presented in Section 2.3.2 are not utilized.

The results from Base scenario are showing the optimal investment and operation of the Danish energy system until 2050. Investments and operation of residential HPs is obtained alongside optimal solution. NoIHP scenario shows how the optimal configuration of the Danish energy system changes without installation of new residential HPs. Such a system is definitely technically feasible, but the changes in results are indirectly showing the importance of residential heat pumps. The comparison between results of Base and NoCIHP scenarios shows how significant the introduced spatial constraints are. To ensure that the model is not going to base the development of future Danish energy system on imported electricity, Denmark is constrained to be a net exporter of electricity in all scenarios.

\section{Results}

The production of electricity and heat delivery to residential consumers are addressed in Section 4.1, heat supply from individual heating sources in 4.2, the total system costs in 4.3, while $\mathrm{CO}_{2}$ emissions and fuel consumption are addressed in Section 4.4.

\subsection{Electricity production and heat supply to residential consumers}

Due to minor differences between electricity production in Base, NOiHP and NoCIHP scenarios, only electricity production in Base scenario until 2050 is presented in Error! Reference source not found. Before 2020, more than half of electricity is produced by centralized coal-based CHPs, while offshore and onshore wind turbines are contributing in smaller shares. This is changing in 2020 due to the constraint that at least $50 \%$ of electricity 
consumption needs to be produced from wind power. The larger investments in offshore wind turbines are postponed to 2035 because their investment costs are decreasing over time. The existing natural gas CHPs are not utilised in 2020 while the decrease in production from coalbased CHPs is caused by decommission of part of its capacity. The decrease in production from gas and coal in 2020 is compensated by the increase in offshore wind production and reduced export. Due to the constraint that Denmark needs to be a net exporter of electricity in all scenarios, reduced export leads to reduced import of electricity. Even though the production from coal-based CHPs is less expensive than imports, very moderate reinvestments in coal-based CHPs are occurring because of the short window for fossil fuels until 2035. The share of electricity which is produced from coal-based CHPs drops to $37 \%$ in 2020, while onshore and offshore wind turbines are adding $27 \%$ and $26 \%$, respectively. Already in 2020, the entire onshore wind potential becomes utilised; the amounts of renewable electricity produced from offshore wind are growing all the way until 2050. After 2035, the Danish power system becomes free of fossil fuels - around $80 \%$ of electricity is then produced from offshore wind and around $20 \%$ from onshore wind.

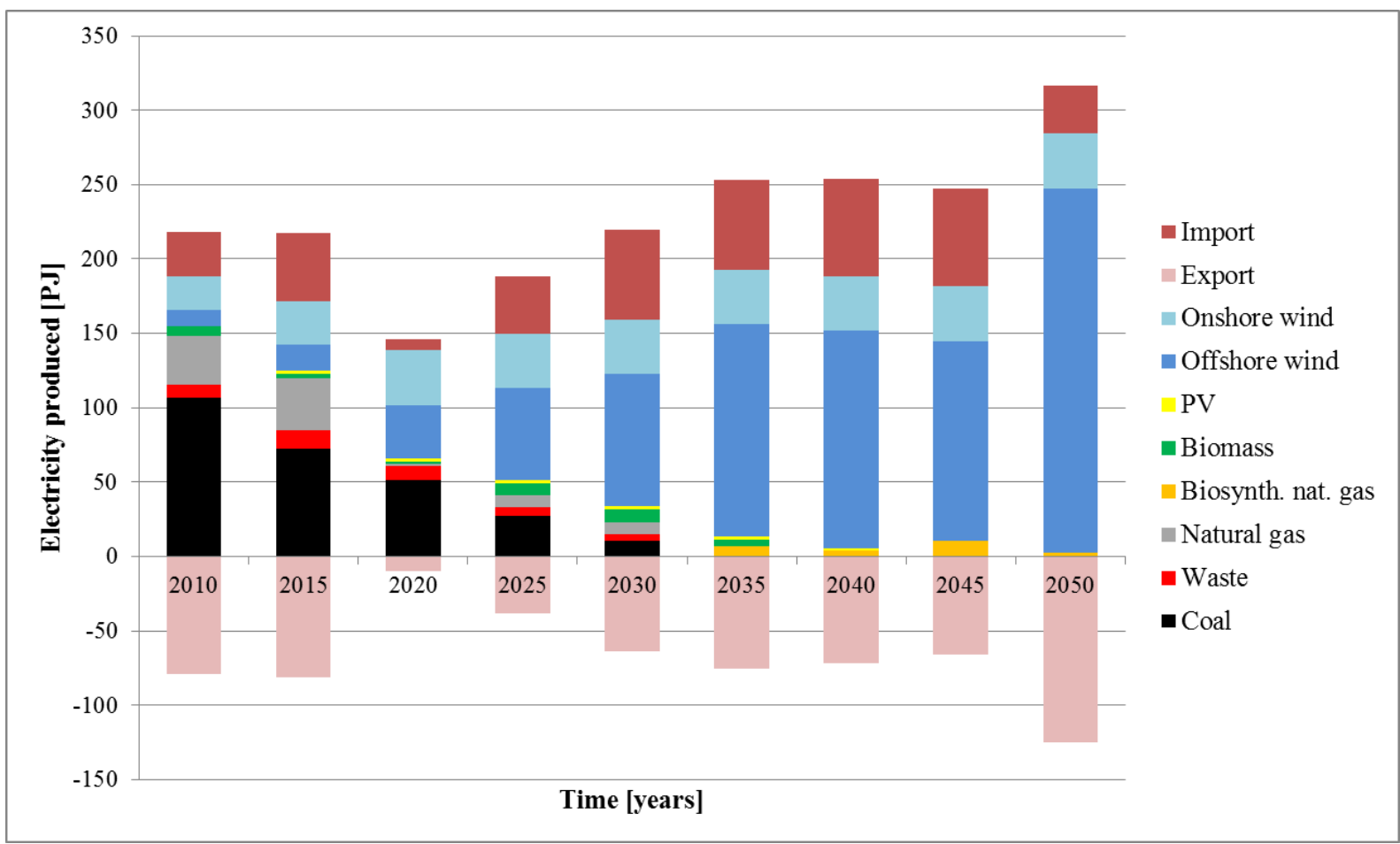

Figure 4. Electricity production in the Danish energy system

Heat delivered to residential consumers until 2050 in all analysed scenarios is presented in Error! Reference source not found.. In Base scenario, Central DH covers between 30 and $42 \%$ of residential heating demand between 2010 and 2050, Decentral DH supplies between 18 and $22 \%$, while the remaining part of heating demand is covered by individual heating sources. In NoIHP scenario, share of residential heating demand covered by district steadily grows from $48 \%$ in 2010 to $69 \%$ in 2050. In both Base and NoIHP scenario, Central DH seems to be robust heat supply option, because it is covering over $40 \%$ of residential heating demand after 2035 in Base and over $44 \%$ in NoIHP scenario. This is the consequence of connecting of individually heated buildings located within district heating areas to district heating. In NoCIHP scenario, the installation of residential GSHPs is not constrained in the model despite sufficient ground area might not be available. This is resulting in more individual heating solutions compared to the other two scenarios. In all scenarios, heat 
savings appear to be inexpensive solution for reducing heating demand. The combination of heat saving measures, demolition of existing and construction of new buildings is reducing the residential heating demand by $25 \%$ until 2050 .

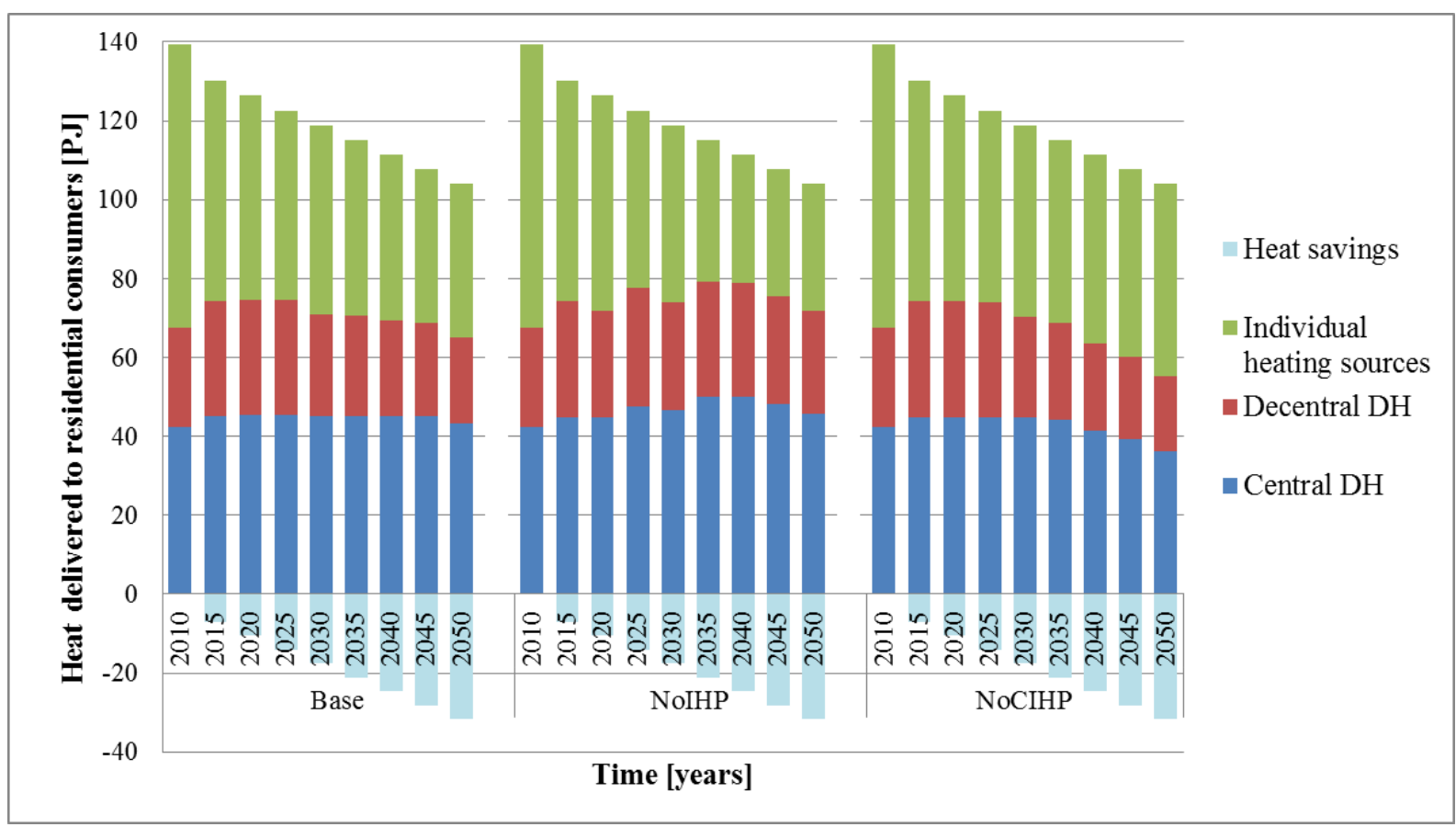

Figure 5. Heat delivered to residential consumers

\subsection{Heat supply from individual heating sources}

Heat delivered to residential consumers from individual heating sources until 2050 is presented in Error! Reference source not found.. Some similarities can be observed among the scenarios. First, significant heat savings occur from 2010 to 2020. Second, existing natural gas boilers are not being utilised after 2015. The model instead finds that natural gas heat pumps are a part of optimal solution for heat supply before 2035. The use of fossil fuels is not allowed after 2035. Third, solar heating appears to be an inexpensive heat supply option - it covers $20-30 \%$ of heat production from individual sources in all scenarios and is limited by the available roof area. Some differences between analysed scenarios can be observed as well. First, in the period after 2020, heat production from individual heating sources is the lowest in NoIHP scenario and the highest in NoCIHP scenario. Second, after 2035 biomass boilers only appear in NoiHP scenario in which the installation of new residential HPs is not allowed.

The role of residential HPs can be observed when productions from individual heating sources are compared among the analysed scenarios. After comparing Base and NoCIHP scenarios, it can be concluded that the available ground area is a constraining factor for the energy system, i.e. it would be beneficial from the energy system point of view to install more GSHPs if more ground area would be available. To illustrate that, the production from GSHPs in 2050 in NoCIHP scenario is 3.8 times higher than in Base scenario. After comparing NoIHP with Base scenario, it can be observed that the heat production from individual sources is reduced by $20 \%$ as a result of joint actions of heat savings and expansion of district heating. This means that individual heating solutions are losing 
competitiveness if residential HPs are not considered as a supply option. The associated negative effects on overall system economy will be elaborated in the following sub-section.

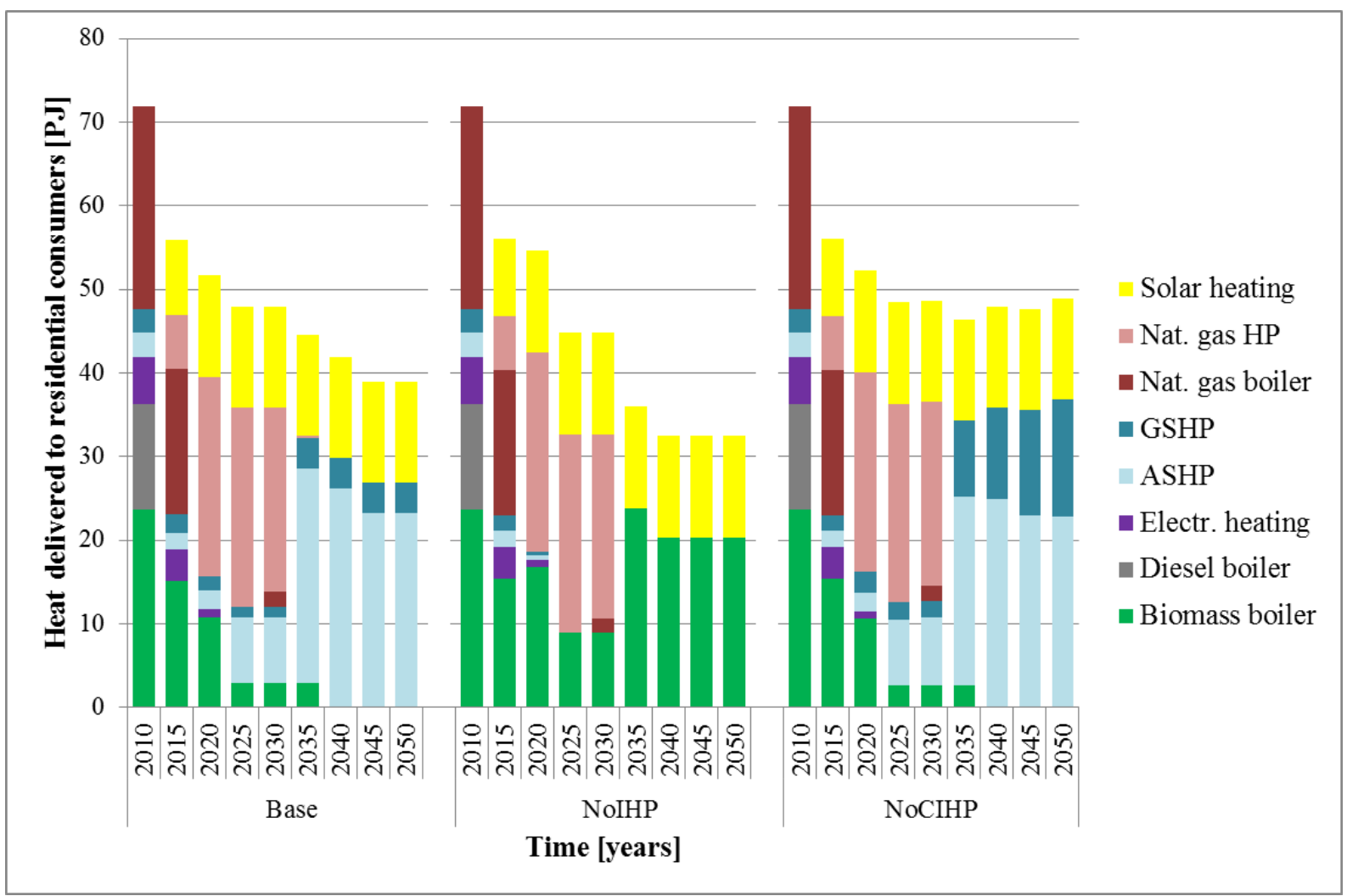

Figure 6. Heat delivered to residential consumers from individual heating sources

\subsection{Total system costs}

The different components of undiscounted system costs are shown in Error! Reference source not found. When compared to Base scenario, the total undiscounted system costs are $0.3 \%$ lower in NoCIHP and $16 \%$ higher in NoIHP scenario. All components of total undiscounted system costs in NoIHP scenario are within $+/-5 \%$ range compared to Base scenario, except fuel costs which are $70 \%$ higher. The increased fuel costs are a consequence of the increased import of wood pellets which are used in individual biomass boilers, especially after 2035. The sum of investment, fixed and variable O\&M and fuel costs are the same for Base and NoCIHP scenario. The difference in total undiscounted system costs originates from greater salvage values and earnings from electricity trade. The sum of salvage values in the system is greater in NoCIHP compared to Base scenario due to higher installed capacities of large offshore wind turbines and residential HPs. Greater earnings from electricity trade are achieved in NoCIHP scenario because of lower expenditures for import from Sweden starting from 2035 and higher earnings from export to Germany starting from 2040. The increased exports and lower imports are results of decreased electricity demand, i.e. the difference between electricity demands of residential HPs compared to large-scale HPs in DH areas. 


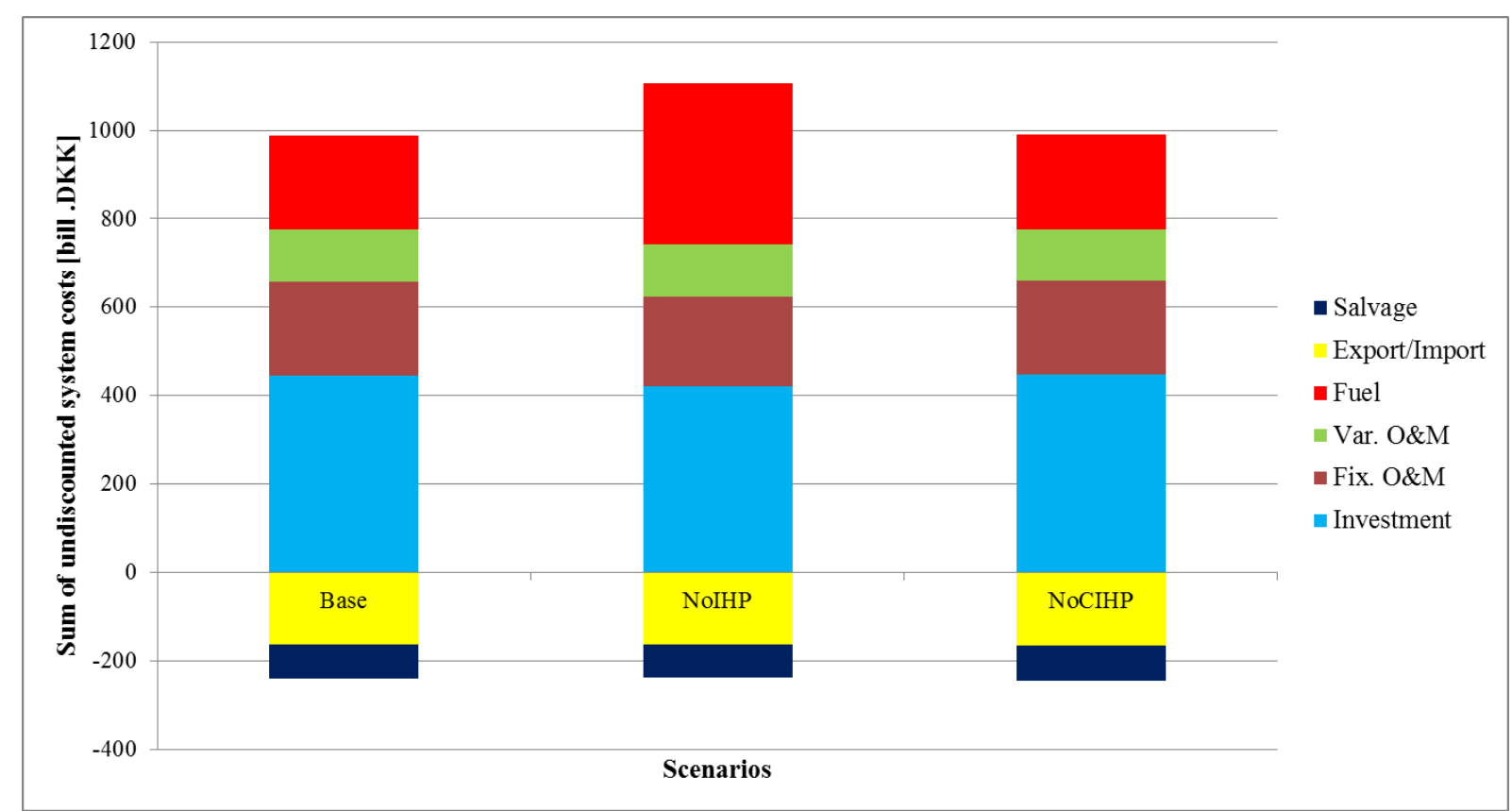

Figure 7. Total undiscounted system costs

\section{$4.4 \mathrm{CO}_{2}$ emissions and fuel consumption}

Total emissions of $\mathrm{CO}_{2}$ from residential and power and heat sectors until 2050 in Base, NoIHP and NoCIHP scenarios amount to 424.5, 422.5 and 424.3 Mt, respectively. Since the optimisation performed by TIMES-DK is by nature economic optimisation, fuel consumption and $\mathrm{CO}_{2}$ emissions are obtained as a by-product alongside the optimal solution. The existing capacities in the base year are operated in the same manner in all scenarios, so the differences in $\mathrm{CO}_{2}$ emissions and fuel consumption are coming from investments and operation of technologies installed after 2010. The differences in $\mathrm{CO}_{2}$ emissions occur only before 2035 , because after 2035 only waste incinerators are allowed to emit $\mathrm{CO}_{2}$.

The differences between Base and NoCIHP scenario in both fuel consumption and $\mathrm{CO}_{2}$ emissions are minor - Centralized coal-based CHPs built in 2020 and operated until 2035 produce $5 \%$ more heat in Base scenario. Besides that, DH production from large-scale HPs in Base scenario is evened out by the increased production from residential HPs in NoCIHP scenario. This does not create any difference in fuel consumption or environmental emissions.

The differences in $\mathrm{CO}_{2}$ emissions between Base and NoIHP scenarios are mostly determined by the way how DH is produced between 2015 and 2035. In Base scenario the model invests in a mix of coal CHPs and large-scale HPs, while in NoIHP scenario investments are made solely in large-scale HPs. Instead from residential heat pumps, individual heating in NoIHP scenario is produced from wood pellet boilers, resulting in higher consumption of biomass starting from 2040. The use of combustible waste and associated $\mathrm{CO}_{2}$ emissions are the same in all scenarios, since they are determined by the constraint that entire available combustible waste in the energy system needs to be incinerated.

\section{Sensitivity analysis}


The most influential parameters for the investments and operation of the Danish energy system until 2050 are varied in order to discover how sensitive the model's results are. For each of sixteen sensitivity actions, the following variables are compared with their values in

Base scenario:

- Total system costs,

- Cumulative $\mathrm{CO}_{2}$ emissions over the analysed period,

- Productions from offshore and onshore wind turbines, district heating, ASHPs, and GSHPs

The sensitivity actions imply a change of the following input parameters:

- Investment costs of wind turbines, ASHPs and GSHPs by $+/-10 \%$ and DH expansion by $+/-20 \%$,

- Biomass price by $+/-10 \%$ and $+/-20 \%$,

- $\mathrm{k}_{\text {area }}$ (the percentage of a parcel area available for burring horizontal pipes) to 0.8 ,

- Available heat saving potential to $50 \%$ and 0 ,

- COPs to annual averages.

The summary of sensitivity analysis is presented in Table 4 . The general results presented in Section 4 are confirmed when sensitivity analysis is undertaken, even though heat production from individual heating sources did not prove to be very robust to changes in input parameters.

Table 4. Summary of sensitivity analysis

\begin{tabular}{|c|c|c|c|c|c|c|c|c|}
\hline \multirow{2}{*}{$\begin{array}{l}\text { Sensitivity } \\
\text { action }\end{array}$} & \multicolumn{8}{|c|}{ Change of results relative to Base scenario } \\
\hline & \begin{tabular}{|l|}
$\begin{array}{l}\text { System } \\
\text { costs }\end{array}$ \\
\end{tabular} & \begin{tabular}{|l|}
$\mathrm{CO}_{2}$ \\
emissions
\end{tabular} & $\begin{array}{l}\text { Onshore } \\
\text { wind } \\
\text { production }\end{array}$ & $\begin{array}{l}\text { Offshore } \\
\text { wind } \\
\text { production }\end{array}$ & \begin{tabular}{|l|} 
DH \\
production
\end{tabular} & \begin{tabular}{|l|} 
GSHP \\
production
\end{tabular} & \begin{tabular}{|l|} 
ASHP \\
production
\end{tabular} & \begin{tabular}{|l|} 
Biomass \\
boilers \\
production
\end{tabular} \\
\hline $\begin{array}{l}-10 \% \text { investment } \\
\text { costs of ASHPs }\end{array}$ & $-0.4 \%$ & $0.4 \%$ & $0.0 \%$ & $-1.8 \%$ & $-5.4 \%$ & $-21.7 \%$ & $38.9 \%$ & $-22.7 \%$ \\
\hline $\begin{array}{l}-10 \% \text { investment } \\
\text { costs of GSHPs }\end{array}$ & $-0.1 \%$ & $0.1 \%$ & $0.0 \%$ & $-0.9 \%$ & $-0.9 \%$ & $53.2 \%$ & $2.9 \%$ & $-13.3 \%$ \\
\hline $\begin{array}{l}-10 \% \text { investment } \\
\text { costs of wind turbin. }\end{array}$ & $-2.9 \%$ & $0.3 \%$ & $0.0 \%$ & $19.6 \%$ & $1.2 \%$ & $8.2 \%$ & $3.2 \%$ & $-25.0 \%$ \\
\hline $\begin{array}{l}-10 \% \text { price of } \\
\text { biomass }\end{array}$ & $-1.1 \%$ & $-1.6 \%$ & $0.0 \%$ & $-3.4 \%$ & $-3.9 \%$ & $-23.9 \%$ & $-15.6 \%$ & $94.6 \%$ \\
\hline $\begin{array}{l}-20 \% \text { price of } \\
\text { biomass }\end{array}$ & $-2.5 \%$ & $-5.5 \%$ & $0.0 \%$ & $-7.1 \%$ & $-14.0 \%$ & $-41.6 \%$ & $-39.7 \%$ & $288.8 \%$ \\
\hline $\begin{array}{l}-20 \% \text { inv. costs of } \\
\text { DH expansion }\end{array}$ & $-0.2 \%$ & $0.2 \%$ & $0.0 \%$ & $-0.7 \%$ & $0.9 \%$ & $-1.5 \%$ & $-5.4 \%$ & $2.4 \%$ \\
\hline $\begin{array}{l}+10 \% \text { investment } \\
\text { costs of ASHPs }\end{array}$ & $0.2 \%$ & $-0.4 \%$ & $0.0 \%$ & $-1.1 \%$ & $2.0 \%$ & $-1.1 \%$ & $-26.8 \%$ & $41.8 \%$ \\
\hline $\begin{array}{l}+10 \% \text { investment } \\
\text { costs of GSHPs }\end{array}$ & $0.0 \%$ & $-0.1 \%$ & $0.0 \%$ & $-0.2 \%$ & $0.4 \%$ & $-54.4 \%$ & $2.3 \%$ & $10.4 \%$ \\
\hline $\begin{array}{l}+10 \% \text { investment } \\
\text { costs of wind turbin. }\end{array}$ & $2.5 \%$ & $2.5 \%$ & $0.0 \%$ & $-14.0 \%$ & $-1.0 \%$ & $-24.1 \%$ & $-3.2 \%$ & $29.4 \%$ \\
\hline $\begin{array}{l}+10 \% \text { price of } \\
\text { biomass }\end{array}$ & $0.7 \%$ & $2.2 \%$ & $0.0 \%$ & $-0.6 \%$ & $2.0 \%$ & $12.5 \%$ & $0.7 \%$ & $-33.7 \%$ \\
\hline $\begin{array}{l}+20 \% \text { price of } \\
\text { biomass }\end{array}$ & $1.3 \%$ & $3.9 \%$ & $0.0 \%$ & $1.0 \%$ & $2.5 \%$ & $8.5 \%$ & $-0.2 \%$ & $-36.1 \%$ \\
\hline $\begin{array}{l}+20 \% \text { inv. costs of } \\
\text { DH expansion }\end{array}$ & $0.2 \%$ & $0.0 \%$ & $0.0 \%$ & $-0.2 \%$ & $-1.5 \%$ & $1.4 \%$ & $10.2 \%$ & $-5.9 \%$ \\
\hline $\begin{array}{l}\text { reduction factor } \\
\mathrm{k}_{\text {area }}=0.8\end{array}$ & $-0.01 \%$ & $0.0 \%$ & $0.0 \%$ & $0.0 \%$ & $-0.4 \%$ & $23.0 \%$ & $-1.5 \%$ & $-0.5 \%$ \\
\hline
\end{tabular}




\begin{tabular}{|l|l|l|l|l|l|l|l|l|}
\hline $\begin{array}{l}\text { Fixed COPs over } \\
\text { whole year }\end{array}$ & $-0.2 \%$ & $-0.3 \%$ & $0.0 \%$ & $-2.0 \%$ & $-1.6 \%$ & $-1.5 \%$ & $9.5 \%$ & $-2.9 \%$ \\
\hline $\begin{array}{l}-50 \% \text { out of total } \\
\text { heat saving potential }\end{array}$ & $0.1 \%$ & $0.1 \%$ & $0.0 \%$ & $-0.1 \%$ & $-1.8 \%$ & $0.2 \%$ & $12.8 \%$ & $-8.4 \%$ \\
\hline $\begin{array}{l}\text { Forbidding heat } \\
\text { savings }\end{array}$ & $8.5 \%$ & $0.9 \%$ & $0.0 \%$ & $3.2 \%$ & $4.8 \%$ & $3.9 \%$ & $82.2 \%$ & $45.5 \%$ \\
\hline
\end{tabular}

Not allowing to the model to invest in heat saving measures has the biggest effect on the total system costs. Even though this is not a realistic sensitivity action, it shows the importance of heat saving measures for overall system's economy. Due to high shares of electricity production from wind turbines, totals system costs are also highly sensitive to the investment costs of wind turbines.

The cumulative $\mathrm{CO}_{2}$ emissions over the whole analysed period are less volatile then the total system costs - they are within $(-5.5 \%,+3.9 \%)$ range. The main reason for that is the constraint that production of electricity and heat from fossil fuels is not allowed starting from 2035, i.e. the only allowed $\mathrm{CO}_{2}$ emissions after 2035 are from waste incineration. The price of biomass has the biggest effect on cumulative $\mathrm{CO}_{2}$ emissions.

The electricity production from onshore wind turbines is not affected by any sensitivity measure. The reason for that is the constraint that at least $50 \%$ of electricity consumption needs to be produced from wind power starting from 2020 and that total costs of onshore wind turbines are lower than the costs of offshore wind turbines. The reduction of investment costs of wind turbines by $10 \%$ is increasing the production from offshore wind turbines by $19.6 \%$, while the increase by $10 \%$ decreases its production by $14 \%$. The electricity production from offshore wind turbines is significantly affected by the reduction of biomass price - decrease of its price by $20 \%$ entails the reduction of production from offshore wind turbines by $7.1 \%$. The reason behind this is that cheaper biomass becomes part of electricity production through CHPs thus replacing offshore wind turbines. In addition to that, share of biomass boilers increases and thus replaces residential heat pumps and lowers residential electricity demand.

From the sensitivity analysis, district heating seems as a robust supplier of heat, as it is affected only by a decrease of biomass price and complete forbidding of heat savings. In the first case, biomass CHPs move more towards electricity production while production of biomass boilers increases at the expanse of district heating. In the second case, DH is expanding and is increasing the production by $4.8 \%$.

The heat production from biomass boilers, ASHPs and GSHPs is highly dependent on input assumptions, especially biomass price, but also investment costs of ASHPs, GSHPs and wind turbines. Two sensitivity actions relate to the two novel approaches presented in the present paper and thus should be especially elaborated. First, changing area reduction factor $\mathrm{k}_{\text {area }}$ to 0.8 allows for bigger share of parcel area to be utilised for installation of GSHPs. This is resulting in the increase of production from GSHPs of $23 \%$, meaning that the increase in production from GSHPs would be optimal from energy system point of view, but the availability of ground area is an important constraint. Second, using annual average instead of temperature-dependant COPs is resulting in the increase of production from ASHPs at the expanse of production from GSHPs, DH and biomass boilers. The use of annual average COPs favours heat pumps because they are more efficient in periods with lower outdoor temperature and higher heat demand and less efficient in periods with higher outdoor temperature and lower heat demand. ASHPs are favoured more than GSHPs because changes of air temperature are more pronounced than changes of ground temperature. 


\section{Discussion}

The results of the present study are in line with the results of previous studies. The results of studies [3-18] are suggesting that from the socio-economic perspective residential heat pumps should be present in areas with low heat density in which district heating is not competitive. Our results confirm this.

Several studies [14-17] claimed that residential heat pumps are contributing to the integration of wind power, reduction of environmental emissions and the total system costs. Our results can confirm that - heat pumps are present in the energy system characterized by fossil fuel free production of electricity and heat from 2035 as well as in renewable energy system in 2050. Since the optimization performed by TIMES-DK is always resulting in minimal total system costs, then we can also claim that residential heat pumps are contributing to the reduction of the total system costs.

Neither of these studies have analysed whether there is enough ground area to install groundsource heat pumps. The available ground area proved to be an important limitation because it would be beneficial for the entire energy system to install more ground-source heat pumps, but there is not enough ground area. This limitation is physical, because sufficient ground area is needed to extract enough heat to be able to supply enough heat to residential buildings. If significant reductions of heating demands occur in the future, less ground area will be needed and it might be necessary to revise these limitations.

The previous studies also did not consider that COPs of residential heat pumps are dependent on air and ground temperatures. As a result of that, they are more efficient when the heating demand is low and less efficient when the heating demand is high. We have proved that the use of variable COPs affects the operation of heat pumps, especially ASHPs since the air temperature drops heavily in winters.

Despite the fact that both variable COPs and ground area constraints are negatively affecting the position of residential heat pumps compared to other technologies our results still show that they are responsible for producing two thirds of total heat from individual heating technologies. Even though they have high investment costs compared to other technologies, their competitiveness in the future Danish energy system can be explained by high efficiency. At the same time, they are not utilising the biomass resources, which can be better utilised in other sectors of the energy system, for example for production of biofuels for the transportation sector.

\section{Conclusion}

Two novel approaches regarding modelling of residential heat pumps were introduced within the present paper. First, COPs are modelled as temperature-dependent instead of traditional approach in which constant COPs over whole year are used. This is done to improve representation of annual operation of residential heat pumps - they operate with COPs higher than average in summers when heat demands are low and COPs lower than average in winters when heat demands are high; this is especially pronounced in the case of air-source heat pumps. This way of modelling COPs have an impact on the results. If fixed COPs would be used, total system costs would be $0.2 \%$ lower, $\mathrm{CO}_{2}$ emissions $0.3 \%$ lower, while production from air-source heat pumps would be $9.5 \%$ higher. Second, available ground area was used as constraining factor for installation of ground-source heat pumps. GIS tools were used to determine the buildings with sufficient parcel area to be able to place enough horizontal pipes and thus cover its heating demand by ground-source heat pumps. This 
constraint proved to influence the results. If this constraint would be ignored, this would result in $0.3 \%$ lower total system costs and 2.7 time higher production from ground-source heat pumps.

The role of residential heat pumps in the future Danish energy system until year 2050 was analysed by TIMES-DK model which optimizes both investments and operation. Based on the analysed scenarios it can be concluded that residential heat pumps play an important role in the future Danish energy system - they are responsible for production of 66-70\% of heat from individual heating sources. This corresponds to $24-28 \%$ of total heat demand after 2035. On the other hand, Danish energy system can function without investments in residential heat pumps but this implies the increase of the total system costs by $16 \%$ and the use of biomass by $70 \%$.

\section{Future work}

There are several natural extensions to the presented analysis. The shares of parcels' areas available for laying down the horizontal pipes $\mathrm{k}_{\text {area }}$ and specific extraction power from ground $\mathrm{P}_{\mathrm{h}, \mathrm{spec}}$ should be further examined and assigned to different geographical areas and building types. As a first step in that direction, ten residential buildings in Denmark should be chosen (one single-family and one multi-family building in each of the five regions) and the obtained results should be analysed. Noise is a by-product of operation of ASHPs. Whether this could be a limiting factor for their implementation in multi-family buildings should be addressed within the future work. The use of seasonal instead of annual average COPs proved to have an impact on the results. The impact of using even more detailed temporal changes of COPs should be further examined. Finally, since in several studies residential heat pumps proved to be socio-economically competitive in areas where district heating is not competitive, it would be interesting to analyse them from the private-economic perspective. This will help us to understand why are they supplying only $2 \%$ of residential heating demand in 2014.

\section{Acknowledgment}

The development of TIMES-DK model utilised in this paper was funded by the Danish Energy Agency. The work presented in this paper is a result of the research activities of the Strategic Research Centre for $4^{\text {th }}$ Generation District Heating (4DH), which has received funding from Innovation Fund Denmark.

\section{References}

1. Danish Ministry of Climate, Energy and Buildings, "The Governments' energy and climate political goals and the results of the energy agreement in 2020" <http://www.kebmin.dk/sites/kebmin.dk/files/klima-energi-bygningspolitik/dansk-klimaenergibygningspolitik/energiaftale/Faktaark\%202\%20energi\%20og\%20klimapolitiske\%20mal. pdf $>$; 2012. [accessed 15.04.15] [in Danish]

2. The Danish Government. Our energy. <http://www.ens.dk/DA-DK/politik/dansk-klimaog-energi-politik/voresenergi/Sider/Forside.aspx>; 2011 [accessed 15.04.15] [in Danish]. 
3. Munster, M., Morthorst, P. E., Larsen, H. V., Bregnbaek, L., Werling, J., Lindboe, H. H., \& Ravn, H. (2012). The role of district heating in the future Danish energy system. Energy, 48(1), 47-55. doi:10.1016/j.energy.2012.06.011

4. Lund, H., Möller, B., Mathiesen, B. V., \& Dyrelund, A. (2010). The role of district heating in future renewable energy systems. Energy, 35(3), 1381-1390. doi:10.1016/j.energy.2009.11.023

5. Möller, B., \& Lund, H. (2010). Conversion of individual natural gas to district heating: Geographical studies of supply costs and consequences for the Danish energy system. Applied Energy, 87(6), 1846-1857. doi:10.1016/j.apenergy.2009.12.001

6. Mathiesen, B.V., Lund, H., \& Karlsson, K. B. (2011). 100\% Renewable energy systems, climate mitigation and economic growth. Applied Energy, 88(2), 488-501. doi:10.1016/j.apenergy.2010.03.001

7. Mathiesen, B. V., Lund, H., \& Karlsson, K. (2009). IDAs Klimaplan 2050, baggrundsrapport-Tekniske systemanalyser, brændselsforbrug, drivhusgasser, samfundsøkonomiske konsekvenser, erhvervspotentialer, beskæftigelseseffekter samt helbredsomkostninger (IDAs Climate Plan 2050, background report in Danish and English). Copenhagen: Danish Society of Engineers (IDA, Ingeniørforeningen Danmark).

8. Lund, H., Thellufsen, J. Z., Aggerholm, S., Wittchen, K. B., Nielsen, S., Mathiesen, B. V., \& Möller, B. (2014). Heat Saving Strategies in Sustainable Smart Energy Systems. International Journal of Sustainable Energy Planning and Management, 4, 1-15. doi:10.5278/ijsepm.2014.4.2

9. Zvingilaite, E. (2013). Modelling energy savings in the Danish building sector combined with internalisation of health related externalities in a heat and power system optimisation model. Energy Policy, 55, 57-72. doi:10.1016/j.enpol.2012.09.056

10. Mathiesen, B. V., Lund, H., \& Connolly, D. (2012). Limiting biomass consumption for heating in $100 \%$ renewable energy systems. Energy, 48(1), 160-168. doi:10.1016/j.energy.2012.07.063

11. Sørensen Torekov, M., Bahnsen, N., \& Qvale, B. (2007). The relative competitive positions of the alternative means for domestic heating. Energy, 32(5), 627-633. doi:10.1016/j.energy.2006.10.002

12. Østergaard, P. A., \& Lund, H. (2011). A renewable energy system in Frederikshavn using low-temperature geothermal energy for district heating. Applied Energy, 88(2), 479-487. doi:10.1016/j.apenergy.2010.03.018

13. Østergaard, P. A. (2013). Wind power integration in Aalborg Municipality using compression heat pumps and geothermal absorption heat pumps. Energy, 49(1), 502-508. doi:10.1016/j.energy.2012.11.030

14. Hedegaard, K., Mathiesen, B. V., Lund, H., \& Heiselberg, P. (2012). Wind power integration using individual heat pumps - Analysis of different heat storage options. Energy, 47(1), 284-293. doi:10.1016/j.energy.2012.09.030

15. Hedegaard, K., \& Münster, M. (2013). Influence of individual heat pumps on wind power integration - Energy system investments and operation. Energy Conversion and Management, 75, 673-684. doi:10.1016/j.enconman.2013.08.015

16. Mathiesen, B.V., Lund, H., Connolly, D., Wenzel, H., Østergaard, P.A., Möller, B., Nielsen, S. Ridjan, I., Karnøe, P., Sperling, K., Hvelplund, F.K. (2015). Smart Energy Systems for coherent $100 \%$ renewable energy and transport solutions. Applied Energy, 145, 139-154, doi:/10.1016/j.apenergy.2015.01.075.

17. Meibom, P., \& Karlsson, K. B. (2010). Role of hydrogen in future North European power system in 2060. International Journal of Hydrogen Energy, 35(5), 1853-1863. doi:10.1016/j.ijhydene.2009.12.161 
18. Zvingilaite, E. (2011). Human health-related externalities in energy system modelling the case of the Danish heat and power sector. Applied Energy, 88(2), 535-544. doi:10.1016/j.apenergy.2010.08.007

19. ETSAP homepage. http://www.iea-etsap.org/web/index.asp; [accessed 20.09.14]

20. Labriet, M., \& Loulou, R. (2008). ETSAP-TIAM: The TIMES integrated assessment model Part I: Model structure. Computational Management Science, 5(1-2), 7-40. doi:10.1007/s10287-007-0046-Z

21. Loulou, R. (2008). ETSAP-TIAM: The TIMES integrated assessment model. Part II: Mathematical formulation. Computational Management Science, 5(1-2), 41-66. doi:10.1007/s10287-007-0045-0

22. Documentation of ETSAP modelling tools. http://www.ieaetsap.org/web/documentation.asp [accessed 15.04.15]

23. Overview of TIMES Modelling Tool <http://www.iea-etsap.org/web/Times.asp> [accessed 15.04.15]

24. RISØ DTU \& Ea Energianalyse (2010). Future scenarios and measures, Sector Analysis Electricity and heat supply. <http://www.ens.dk/sites/ens.dk/files/politik/dansk-klimaenergipolitik/klimakommissionen/groen-energi/baggrundsrapporter/

Sektoranalyse_el_og_varmeforsyning.pdf $>$ [accessed 15.04.15] [in Danish]

25. Danish Commission on Climate Change Policy (2010). Green energy - the road to a Danish energy system without fossil fuels.<http://www.ens.dk/politik/dansk-klimaenergipolitik/klimakommissionen/gron-energi> [accessed 15.04.15] [in Danish]

26. Danish Energy Agency (DEA) (2014). Energy Scenarios towards 2020, 2035 and 2050. http://www.ens.dk/sites/ens.dk/files/dokumenter/publikationer/downloads/energiscenarier _-_analyse_2014_web.pdf [accessed 15.04.15] [in Danish]

27. Andersen, F. M., \& Larsen, H. V. (2012). FRIDA: A model for the generation and handling of solid waste in Denmark. Resources, Conservation and Recycling, Resour. Conserv. Recycl, 65, 47-56. doi:10.1016/j.resconrec.2012.04.004

28. Ea Energy Analyses (2013) Analysis of biomass prices - Future Danish Prices for Straw, Wood Chips and Wood Pellets. http://www.ens.dk/sites/ens.dk/files/undergrundforsyning/vedvarende-energi/bioenergi/analyse-bioenergi-

danmark/analysis_of_biomass_prices_2013.06.18_-_final_report.pdf [accessed 15.04.15]

29. Ea Energy Analyses (2014). Update of fossil fuel and CO2 price projection assumptions Convergence Pathway. http://www.ens.dk/sites/ens.dk/files/info/tal-kort/fremskrivningeranalyser-modeller/samfundsoekonomiske-beregnings-

forudsaetninger/2014/convergence methodology_final.pdf [accessed 15.04.15]

30. Energinet.dk (2014). Energinet.dk's analysis assumptions $2014-2035$. http://energinet.dk/SiteCollectionDocuments/Danske\%20dokumenter/El/Energinet\%20dk s\%20analyseforuds\%C3\%A6tninger\%202014-2035\%20maj\%202014\%20final.pdf [accessed 15.04.15]

31. Ministry of Housing, Urban and Rural Affairs (2014). BBR dataset.

32. Petrovic, S., \& Karlsson, K. (2014) Model for Determining Geographical Distribution of Heat Saving Potentials in Danish Building Stock. ISPRS International Journal of GeoInformation, 3(1), 143-165. doi:10.3390/ijgi3010143

33. Danish Energy Agency (2014). Energy statistics 2013. http://www.ens.dk/info/talkort/statistik-nogletal/arlig-energistatistik [accessed 15.04.15] [in Danish].

34. Danish Energy Agency (2014). Building regulations - Energy consumption. http://bygningsreglementet.dk/br10_05_id104/0/42> [accessed 15.04.15] [in Danish].

35. Danish Energy Agency. Elmodelbolig Statistics (2015). http://statistic.electricdemand.dk/ [accessed 15.04.15] [in Danish]. 
36. Danish Energy Agency (2014). Strategy for renovation of buildings. http://www.ens.dk/sites/ens.dk/files/byggeri/Strategi-for-energirenovering-afbygninger/strategi-for-energirenovering-af-bygninger-web-050514.pdf $\quad$ [accessed 15.04.15] [in Danish].

37. Hansen, J. Z., Stephensen, P. \& Kristensen, J. B. (2013). Modeling Household Formation and Housing Demand in Denmark - The Dynamic Microsimulation Model SMILE, DREAM Report, December 2013. <http://www.dreammodel.dk/pdf/HousingDemand2013.pdf> [accessed 15.04.15]

38. Danish Energy Agency (DEA) (2013). Energy producers count 2010-2012.

39. Petrovic, S., \& Karlsson, K. B. (2014). Danish heat atlas as a support tool for energy system models. Energy Conversion and Management, 87, 1063-1076.

40. Danish Energy Agency (DEA) (2014). Register of wind turbines. < http://www.ens.dk/node/2233/register-wind-turbines > [accessed 15.04.15]

41. Danish Energy Agency (DEA) (2013). Technology Data for Energy Plants - Individual Heating Plants and Energy Transport.

42. Danish District Heating Association (2012). Annual district heating statistics 2011/2012. <http://www.danskfjernvarme.dk/viden-om/aarsstatistik/benchmarking-statistik-20112012> [accessed 15.04.15]

43. P.R. Wang, M. Scharling, K.P. Nielsen (2012). 2001-2010 Design reference year for Denmark, Danish Meteorological Institute. $\langle$ http://www.dmi.dk/fileadmin/Rapporter/TR/tr12-17.pdf $>$ [accessed 20.04.2015] [in Danish]

44. Staffell, I. (2009). Review of Domestic Heat Pump Coefficient of Performance, Birmingham http://wogone.com/science/review_of_domestic_heat_pump_cop.pdf University. 25.04.2015]

45. Staffell, I., Brett, D., Brandon, N., \& Hawkes, A. (2012). A review of domestic heat pumps. ENERGY and ENVIRONMENTAL SCIENCE, 5(11), 9291-9306. doi:10.1039/c2ee22653g

46. Sarbu, I., \& Sebarchievici, C. (2014). General review of ground-source heat pump systems for heating and cooling of buildings. Energy and Buildings, 70, 441-454. doi:10.1016/j.enbuild.2013.11.068

47. Olsen, L. Poulsen, C.S., Vorre, M.H. (2010). Description of potentials - individual heat pumps, Danish Technological Institute. [in Danish]

\section{Tables and figures}


